\title{
Invasive crayfishes as a threat to freshwater bivalves: Interspecific differences and conservation implications
}

\author{
Alexandra Meira a,*, Manuel Lopes-Lima ${ }^{\text {b,c }}$, Simone Varandas ${ }^{\mathrm{d}}$, Amílcar Teixeira ${ }^{\mathrm{e}}$, \\ Francisco Arenas ${ }^{c}$, Ronaldo Sousa ${ }^{\mathrm{a}, \mathrm{c}}$ \\ a CBMA - Centre of Molecular and Environmental Biology, Department of Biology, University of Minho, Campus Gualtar, 4710-057 Braga, Portugal \\ b CIBIO/InBIO - Research Center in Biodiversity and Genetic Resources, University of Porto, Campus Agrário de Vairão, Vairão, Portugal

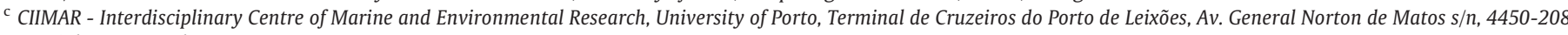 \\ Matosinhos, Portugal \\ d CITAB-UTAD - Centre for Research and Technology of Agro-Environment and Biological Sciences, University of Trás-os-Montes and Alto Douro, Forestry Department, Vila Real, Portugal \\ e CIMO-ESA-IPB - Mountain Research Centre, School of Agriculture, Polytechnic Institute of Bragança, Bragança, Portugal
}

\section{H I G H L I G H T S}

- Invasive crayfishes may threaten native freshwater bivalves.

- Predation of freshwater bivalves by invasive crayfishes was distinct among species.

- Anodonta anatina was the most preyed species.

- Future studies should assess predation of invasive crayfishes on freshwater bivalves.

\section{G R A P H I C A L A B S T R A C T}

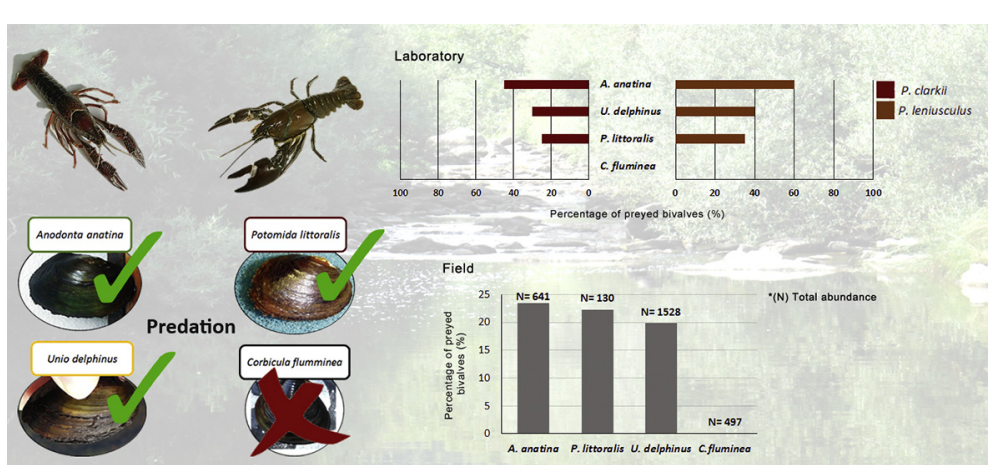

\section{A B S T R A C T}

Freshwater bivalves have suffered major global declines, being the introduction of invasive alien species (IAS) an important, but not well studied, mechanism of threat. This study assessed the predator-prey relationship between two non-native crayfish species (Procambarus clarkii and Pacifastacus leniusculus) and three native (Anodonta anatina, Potomida littoralis and Unio delphinus) and one non-native (Corbicula fluminea) freshwater bivalve species through experiments in laboratory and validation under natural conditions (Sabor River basin, Portugal). All native bivalve species were preyed both in laboratory and in the field; however, both crayfish species were unable to prey C. fluminea. Predation was dependent on crayfish and bivalve species but was not affected neither by crayfish nor bivalve sizes. In the laboratory, the most preyed species by both crayfishes was A. anatina. On average, this species was preyed at least $12 \%$ more than other species, when crayfishes had a choice. Similar results were found in the field. We also found signs of competition between both crayfishes, being $P$. clarkii more dominant and aggressive as this species, on average, manipulated the bivalves $63.6 \%$ more times and 24:33 min longer than P. leniusculus, and initiated 55.8\% more agnostic bouts. Our results support the idea that $P$. clarkii and $P$. leniusculus can affect native freshwater bivalves, but clear interspecific differences were detected. Both crayfishes may have direct and indirect impacts on bivalve populations by increasing mortality or by reducing their fitness. In addition, since both crayfishes do not prey C. fluminea, they offer this IAS

\footnotetext{
* Corresponding author.

E-mail address: alexagmeira@gmail.com (A. Meira).
} 
another advantage over native bivalves. Given the widespread distribution of both $P$. clarkii and $P$. leniusculus and the threatened status of many freshwater bivalves, the dynamics and impacts of this relationship should be taken in account in the implementation of management measures devoted to the conservation of native freshwater bivalves.

(C) 2018 Elsevier B.V. All rights reserved.

\section{Introduction}

The introduction of invasive alien species (IAS) is among the most important, and sometimes irreversible, human-induced changes on ecosystems, being recognized as one of the biggest threats to biodiversity (Sala et al., 2000; Vitousek et al., 1997). IAS can have numerous impacts in terrestrial and aquatic ecosystems (Olden et al., 2004; Simberloff et al., 2013). For example, $69 \%$ of the established aquatic species introduced in six European countries have ecological impacts and these may include changes in biodiversity and ecosystem functioning, trophic interactions and ecosystems' physical properties (GarcíaBerthou et al., 2005; Sousa et al., 2011; Gutiérrez et al., 2014). These changes have possible effects at individual, population, community and ecosystem levels, also leading to high economic losses (Simberloff et al., 2013; Simon and Townsend, 2003; Strayer, 2010; Vilà et al., 2010).

In Europe, numerous crayfish species have been introduced and they can be responsible for several ecological and economic impacts (Gherardi, 2006, Hobbs et al. 1989). Crayfishes can have profound effects in water quality, nutrient dynamics, decomposition and community structure by acting as ecosystem engineers (Carvalho et al., 2016; Creed Jr. and Reed, 2004; Johnson et al., 2010; Matsuzaki et al., 2009; Sousa et al., 2013).

The Signal crayfish Pacifastacus leniusculus (Dana, 1852) is a recognized successful invader (Henttonen and Huner, 1999). This species is native to north-western United States of America (USA) and south western Canada (Bondar et al. 2005; Henttonen and Huner, 1999). It was initially introduced in Europe (Sweden in the 1960s) for stocking purposes and as a commercial substitute of the crayfish species Astacus astacus (Linnaeus, 1758), which became almost extinct in Europe due to the crayfish plague (Gherardi, 2006). The successful establishment of this species encouraged the later introduction of the Louisiana crayfish, Procambarus clarkii (Girard, 1852), in Spain in the 1970s (Gherardi, 2006; Gutiérrez-Yurrita et al., 1999). Procambarus clarkii is listed within the top 10 invasive species in Europe with the highest number of impacts on ecosystem services (DAISIE database, 2018; Vilà et al., 2010). This species is native to north-eastern Mexico through south-central USA east to Florida (Gherardi, 2006; Henttonen and Huner, 1999; Hobbs et al., 1989). Both crayfish species spread throughout Europe with considerable success and are now well established. They are also present in Portugal where they occur in sympatry in Sabor River basin (Bernardo et al., 2011; Gutiérrez-Yurrita et al., 1999). Pacifastacus leniusculus and $P$. clarkii are known to have a highly plastic diet as they are omnivorous and display generalist and opportunistic feeding habits (Guan and Wiles, 1998; Gutiérrez-Yurrita et al., 1998). Procambarus clarkii and $P$. leniusculus may consume large quantities of detritus (e.g. leaf litter) and plants, but they also feed on other animals such as amphibians, fishes, invertebrates, including other crayfishes (Axelsson et al., 1997; Gherardi et al., 2001; Gherardi, 2006; Guan and Wiles, 1998). Their feeding habits are known to have direct and indirect impacts on other species and thus affecting the invaded ecosystems (Axelsson et al., 1997; Gherardi, 2006; Nyström et al., 1996). Even though P. clarkii and P. leniusculus possible impacts and co-existence in many freshwater ecosystems are recognized, little is known about their role as predators of invertebrate species, such as freshwater bivalves.

Bivalves play a major ecological role in freshwater ecosystems (Howard and Cuffey, 2006; Lopes-Lima et al., 2018; Vaughn and
Hakenkamp, 2001; Vaughn et al., 2008); however, in the last decades, freshwater bivalves, especially freshwater mussels from the Unionida order, have suffered a major global decline and are among the most threatened faunal groups in the planet (Lopes-Lima et al., 2014a, 2018; Williams et al., 1993). Since crayfishes can prey on bivalves, the recent introduction of several crayfish species is a possible important threat to the survival of these animals. Nevertheless, very few studies assessed bivalve predation by invasive crayfishes (e.g. Klocker and Strayer, 2004; Machida and Akiyama, 2013) and so the possible consequences of these introductions remain speculative and almost ignored. Given this knowledge gap, the main aim of this study was to describe the potential impacts of $P$. clarkii and P. leniusculus on four freshwater bivalve species (the mussels Anodonta anatina, Potomida littoralis and Unio delphinus; and the clam Corbicula fluminea) by assessing: i) if predator-prey interactions occur between the invasive crayfishes and bivalves and at what intensity; ii) if some bivalve species are more prone to predation than others; iii) if predation levels depend on predator and prey size; and iv) if P. clarkii and P. leniusculus compete for the bivalves as a prey. Using laboratory experiments and validations in natural conditions, the null hypothesis of the present study was that the crayfishes have no preference for freshwater bivalve species as prey and both crayfish should have a similar behaviour. However, we predicted that species with thicker shells (P. littoralis and C. fluminea) will be less prone to predation and $P$. clarkii will present a more aggressive behaviour than P. leniusculus.

\section{Material and methods}

\subsection{Study area and animals' collection and maintenance}

Sabor River has its source in Zamora province (Spain) and enters in Portugal by crossing the Montesinho mountain (Bragança). This river is a tributary of Douro River and has a wide range of environmental conditions: elevation range between 100 and $1500 \mathrm{~m}$, total annual precipitation between 443 and $1163 \mathrm{~mm}$, mean annual temperature between 6.9 and $15.6{ }^{\circ} \mathrm{C}$. The flow regime in the Sabor River basin is highly seasonal, having some dried streams or disconnected pools during the summer (Filipe et al., 2017). A large dam was built recently in the lower Sabor River and started to operate in 2016. The basin has overall good ecological quality although some problems related with organic pollution and regulation of river flow have arisen over the last years (Sousa et al., 2012).

Throughout this work, three native (A. anatina, P. littoralis and $U$. delphinus) and one non-native ( $C$. fluminea) bivalve species were studied. The four bivalve species have a sympatric distribution in the Sabor River basin also co-existing with the invasive crayfish species P. leniusculus and P. clarkii (Filipe et al., 2017; Sousa et al., 2012).

Bivalves were collected in the Sabor River basin by two researchers using snorkelling. Specimens were found visually or by searching through the bottom with hands. Both crayfish species were collected in the Sabor River basin by consistently placing several small baited traps $(50 \times 30 \times 20 \mathrm{~cm}$; $0.5 \mathrm{~cm}$ mesh) in the river bottom for $24 \mathrm{~h}$. Only mature males were used in the laboratory experiments in order to minimize possible sex bias in the assessment of the predatory behaviour.

After collection, organisms were immediately transported to the laboratory. Bivalves were maintained in aquariums $(60 \times 30 \times 30 \mathrm{~cm})$ with 
Table 1

Size range of the specimens of each bivalve and crayfish species used in the laboratory experiments.

\begin{tabular}{ll}
\hline Bivalve species & Size range $(\mathrm{mm})$ \\
\hline Corbicula fluminea & $15-37$ \\
Anodonta anatina & $35-126$ \\
Potomida littoralis & $44-78$ \\
Unio delphinus & $36-97$ \\
\hline Crayfish species & \\
\hline Pacifastacus leniusculus & $74-110$ \\
Procambarus clarkii & $71-120$ \\
\hline
\end{tabular}

$20 \mathrm{~L}$ of water under aeration and fed on microalgae. The specimens of each crayfish species were maintained in separate aquariums $(60 \times 30$ $\times 30 \mathrm{~cm}$ ) in individual small cages with filtrated water under aeration and fed daily with freshwater fish food sticks. All organisms were always maintained under controlled temperature $\left(15^{\circ} \mathrm{C}\right)$ and photoperiod ( $12 \mathrm{~h}$ in the dark and $12 \mathrm{~h}$ with light).

\subsection{Laboratory experiments}

Permits to conduct laboratory experiments and field surveys were obtained from the Portuguese Conservation Governmental Authority (reference: 203 to 206/2017/CAPT). All ethical requisites were accomplished, being the native animals used in the laboratory studies released in the collection sites after the experiments.

For each experiment animals were placed in plastic containers with $3 \mathrm{~cm}$ of fine sand previously washed to promote the interactions between crayfishes and bivalves, and offering crayfish the perfect scenario for predation, but allow bivalves to partly bury in the sediments. The containers were filled with $10 \mathrm{~L}$ of water and maintained under controlled temperature $\left(15^{\circ} \mathrm{C}\right)$ and the experiments ran for $72 \mathrm{~h}$. Specimens were only used once and their size was measured (Table 1 ).

Before the experiments, crayfishes were starved for 3 days to promote their need for nutrition and reduce the effect of previous feeding condition. At the end of each experiment (see below), predation was assessed by checking for the presence of characteristic predation marks on bivalve shells (see Fig. 1A and Machida and Akiyama, 2013) and by visually estimating the percentage of missing shell due to predation comparing to the total shell area.

\subsection{Predation experiments}

The first experiment (Fig. 1B) aimed to determine if: i) P. leniusculus and $P$. clarkii recognized the bivalve species as prey; ii) predation success (whether crayfishes were able to prey on bivalves or not) was dependent on bivalve species and/or the crayfish species; and iii) predation was size dependent.

For this purpose, a single crayfish was placed in a plastic container with a single specimen of one of the four bivalve species (Fig. 1B). Each bivalve-crayfish combination was replicated 20 times $(N=160)$.

\subsection{Prey preference}

The second experiment (Fig. 1C) aimed to determine if $P$. leniusculus and $P$. clarkii prefer to prey on certain bivalve species. For this, one crayfish of each species was placed on a plastic container with four bivalves (one specimen of each of the four bivalve species; Fig. 1C). Each treatment was replicated 10 times ( $N=20$ for both crayfish species).

\subsection{Crayfish competition}

The third experiment (Fig. 1D) aimed to determine possible competition between $P$. leniusculus and $P$. clarkii for available prey. For this, one specimen of each crayfish species was placed in a plastic container with one specimen of A. anatina (Fig. 1D). The choice of $A$. anatina was based on the results from the two earlier experiments as this species was the most preyed bivalve by both crayfish species (see results). The experiment was replicated 10 times $(N=10)$ and recorded using a webcam (HP® WebCam HD 2300) to assess crayfish behaviour. The time of beginning and ending of all interactions was registered to determine bivalve handling time, the duration of aggressive interactions, and to assess the number of times each of these interactions occurred.

\subsection{Sampling and in situ validation}

In order to validate the results gathered in the laboratory experiments we performed a field survey in Sabor River basin (North-eastern Portugal) (Fig. 1E).

To assess if predation occurs in the natural environment, a total of 51 sites were sampled during July 2017, 45 in Sabor River and 6 in its major tributary, the Maçãs River (Fig. 2). For each site, and for freshwater bivalve ecological characterization, a river stretch with a minimum of $100 \mathrm{~m}$ was surveyed covering the maximum of different habitats as possible (i.e. riffles and pools, banks and center of the channel). These surveys were always performed by a minimum of two researchers using snorkeling and freshwater bivalves were found visually or by handsearching through the bottom when visibility was low. A total of four replicates lasting $15 \mathrm{~min}$ were performed totalizing $60 \mathrm{~min}$ of surveyed time per site. In each site, bivalves were collected, including empty shells, and identified to the species level, their size was measured and the percentage of predation by crayfish was estimated using the same methodology as described above for the laboratory experiments.

The abundance of both crayfish species was assessed in 15 of the 51 sites surveyed for bivalves' characterization during August 2017 (Fig. 2). These 15 sites were located along the entire gradient of the Sabor River not subjected to the reservoir influence in an attempt to cover all the river section surveyed for bivalves. Crayfishes were captured by placing 10 funnel traps baited with dead fish, five rectangular $(50 \times 30 \times 20 \mathrm{~cm}$; $0.5 \mathrm{~cm}$ mesh) and five cylindrical (43 cm diameter; $22 \mathrm{~cm}$ height; $1.5 \mathrm{~cm}$ mesh), per site for $24 \mathrm{~h}$. The crayfishes were identified to the species level, their sex was determined, and their size was measured.

\subsection{Statistical analysis}

All statistical analyses performed were preceded by Shapiro-Wilk test to determine if data had a Gaussian distribution and by the Bartlett test to verify the homogeneity of variance. When data failed these assumptions, we used non-parametric tests.

In the first experiment a 2-way permutational univariate analysis of variance (PERMANOVA, Anderson, 2001) (error type-III), with crayfish (2 levels: P. clarkii and P. leniusculus) and bivalve species (4 levels: A. anatina, U. delphinus, $P$. littoralis and C. fluminea) as fixed factors and percentage of shell loss as response variable, was used to assess the effect of predator and/or prey species on bivalve predation. Pairwise comparisons were used to analyse how predation varied between bivalve species. Pearson's chi-squared and Fisher's exact test of independence were used to test if the percentage of preyed bivalves was significantly different between $P$. clarkii and P. leniusculus and between bivalve species. In addition, a Mann Whitney $U$ and Krustal-Wallis tests were

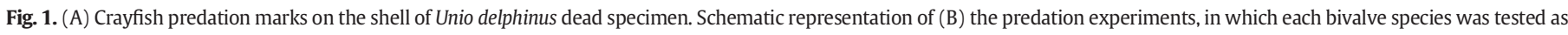

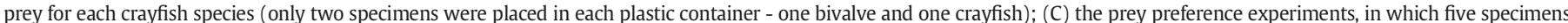

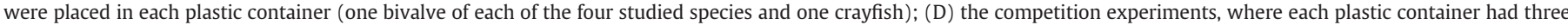
specimens (one specimen of each of the two crayfish species and one specimen of Anodonta anatina); (E) the field validation methodology. 
A

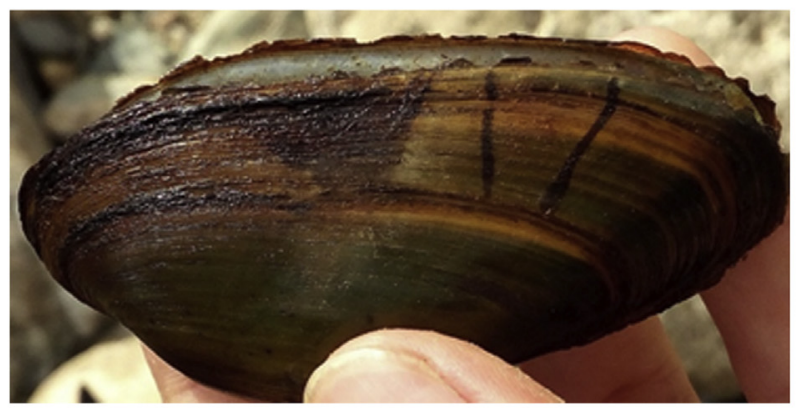

B
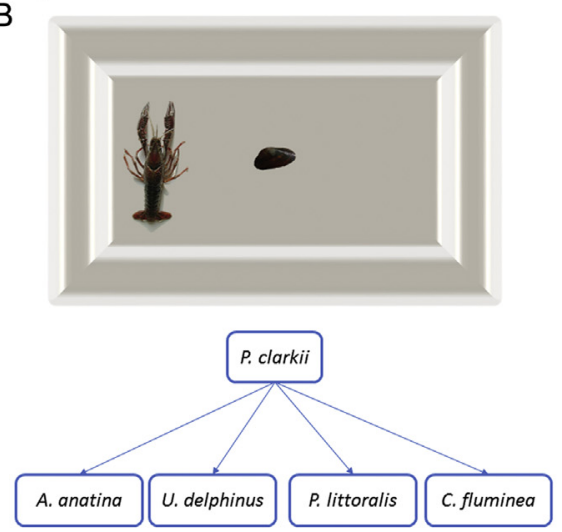

C
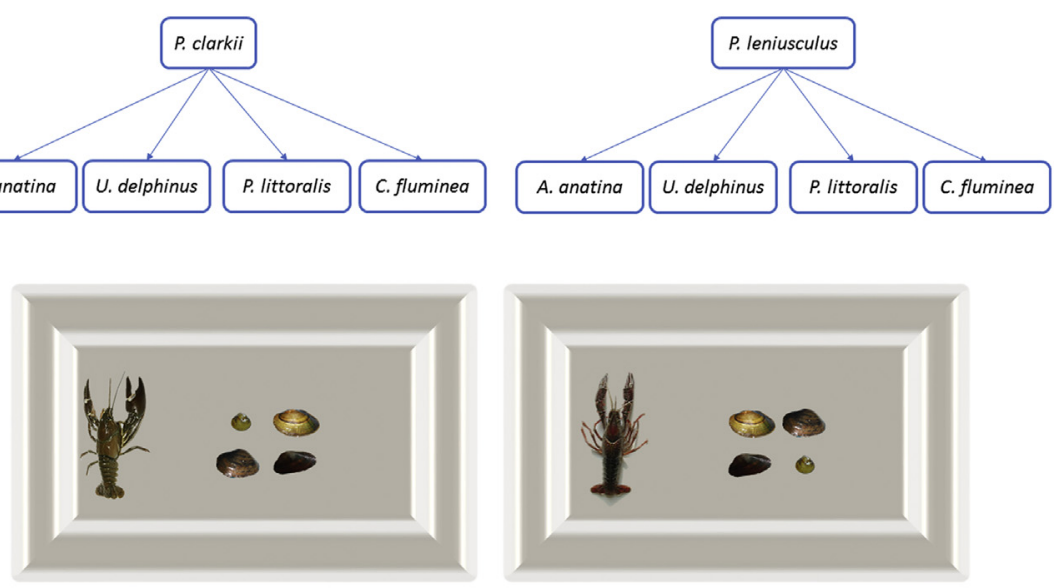

D

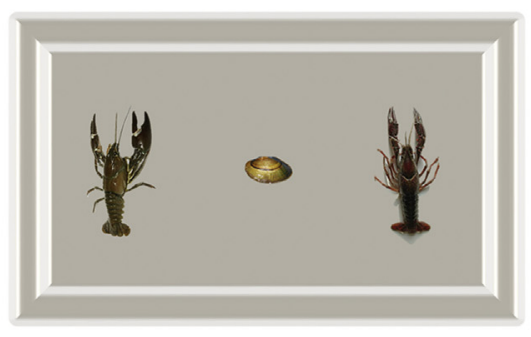

E

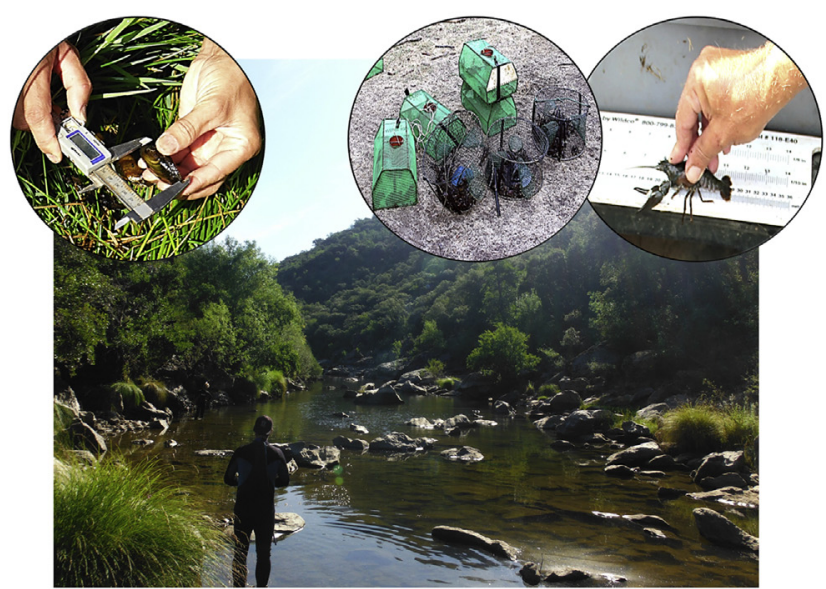




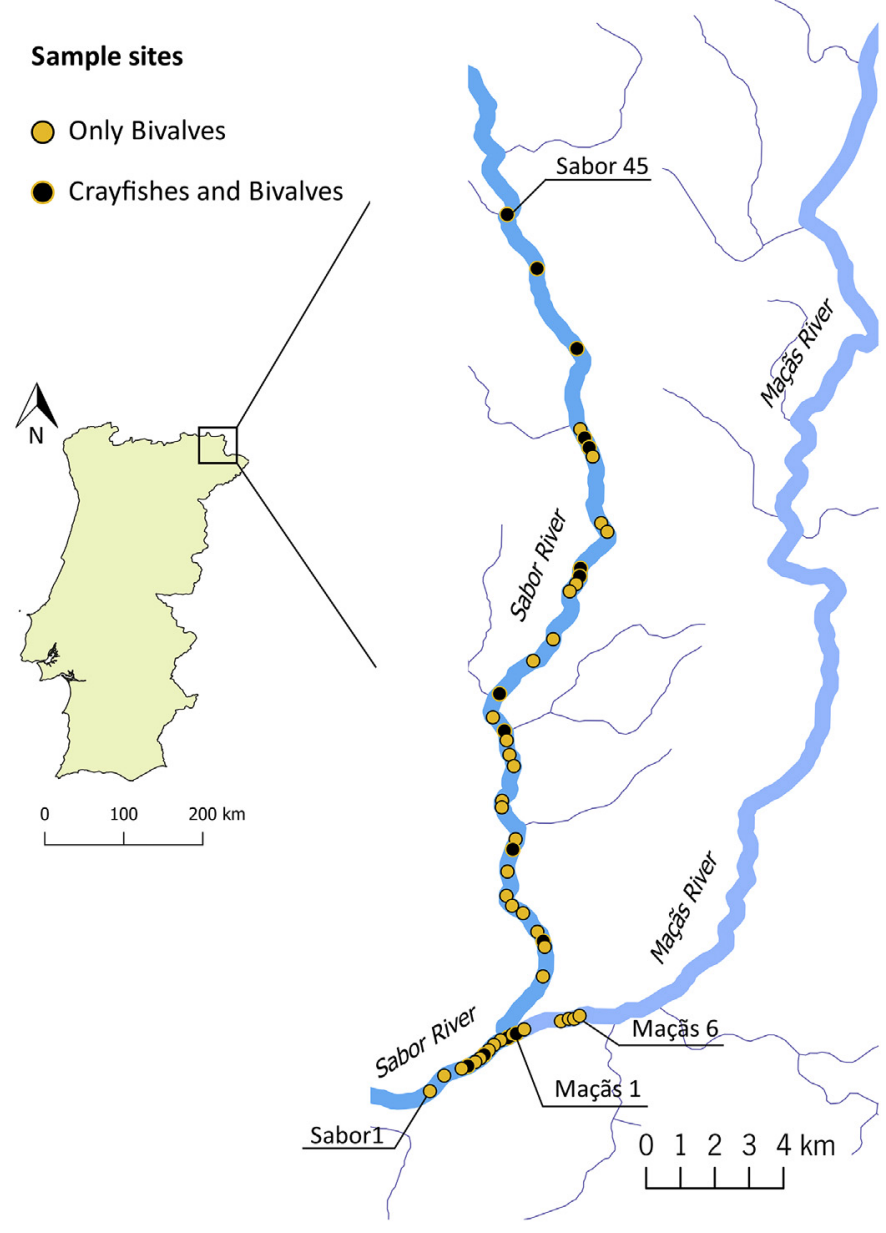

Fig. 2. Map showing the sampling site locations in Sabor and Maçãs Rivers.

performed to, respectively, assess if the crayfishes predated different percentage of preyed bivalves' shells and if that percentage was different between bivalve species. Welch's $t$-test was used to evaluate if predation success depends on bivalve and crayfish sizes, while Spearman's correlations were used to assess the relationship between the percentage of predation and size of the animals.

In the second experiment, a Pearson's chi-squared test (Zar, 2010) was performed between the expected and observed percentage of preyed bivalves when crayfishes had a choice.

In the third experiment, the differences between P. clarkii and $P$. leniusculus on bivalve handling time, percentage of times the bivalve was handled were examined using Wilcoxon matched-pairs signed ranks tests, and differences on the percentage of initiated agonistics bouts were assessed with aa paired $t$-test.

Data collected in the field was analysed using PERMANOVAs (error type-III), with sampling site (24 levels: Sabor 5, Sabor 12 - Sabor 22, Sabor 25 - Sabor 32, Sabor 36, Sabor 39, Sabor 41, Sabor 44) and bivalve species (2 levels: A. anatina and U. delphinus) as fixed factors and percentage of shell loss as response variable, to examine the effect of site and bivalve species predation. Additional permutational pairwise comparisons were used to assess which bivalve species was the most preyed within each site and which sites presented higher predation for each bivalve species. Spearman's correlations were used to test the relationship between the percentage of preyed bivalves and crayfish abundance and sex. A Wilcoxon matched-pairs signed ranks test and paired $t$-tests were performed to assess differences in abundance between crayfish species and differences in the abundance of female and male crayfishes. Finally, a Spearman's correlation was used to test the association of sex ratio
Table 2

Summary of the PERMANOVA results on the effect of crayfish and bivalve species on bivalve shells predation.

\begin{tabular}{lllllll}
\hline Parameter & Effect & df & SS & MS & $\begin{array}{l}\text { Pseudo } \\
\text { F }\end{array}$ & P \\
& & & & & & \\
\hline Shell & Crayfish species & 1 & 44.3 & 44.3 & 3.1636 & 0.0201 \\
consumption & Bivalve species & 3 & 79.76 & 26.6 & 1.8982 & 0.0486 \\
& $\begin{array}{l}\text { Crayfish species } \times \\
\text { bivalve species }\end{array}$ & 3 & 48.6 & 16.2 & 1.1567 & 0.3392 \\
& Error & 152 & 2128.9 & 14.0 & & \\
\hline
\end{tabular}

and the percentage of preyed bivalves. As $P$. littoralis overall abundance was low and its spatial distribution very restricted, no statistical analyses were done with this species.

All PERMANOVAs were performed with 9999 permutations on the basis of Euclidean distances (Anderson, 2001). PERMANOVAs were done with PRIMER 6 (Primer-E, UK) for Windows. All other analyses were done with $\mathrm{R}$ software 3.2.2 for Windows (R Development Core Team, 2015).

\section{Results}

\subsection{Experiment 1: bivalve predation}

Procambarus clarkii and P. leniusculus preyed on all bivalve species except $C$. fluminea. Predation was dependent on crayfish and bivalve species and there was no interaction between these two factors (PERMANOVA, Table 2, Fig. 3A). Despite this, pairwise comparisons showed significant differences only between the native bivalve species and $C$. fluminea. On average, $P$. leniusculus predated a higher percentage of bivalve shells than $P$. clarkii (Fig. 3A). One specimen of $U$. delphinus was killed and had $44.4 \%$ of its shell preyed during the experiment by a signal crayfish. Besides this unusual high value, the maximum shell predation by P. leniusculus was $5.0 \%$ for A. anatina, $7.0 \%$ for $U$. delphinus and $6.5 \%$ for $P$. littoralis. The maximum shell predation by $P$. clarkii was $10.0 \%$ for A. anatina, $5.0 \%$ for $U$. delphinus and $2.0 \%$ for $P$. littoralis.

Considering only preyed bivalves, the average percentage of shell predation was $2.7 \%$ in treatments with $P$. leniusculus and $2.6 \%$ with P. clarkii for A. anatina; $9.0 \%$ and $1.5 \%$ for U. delphinus; and $3.0 \%$ and $1.0 \%$ for $P$. littoralis, respectively (Fig. 3B). On average, $P$. leniusculus predated a higher percentage of shell than $P$. clarkii, but significant differences were only found regarding $U$. delphinus (Mann-Whitney $U$ test, $U=8.00, p=0.036$ ). The percentage of bivalve shell predation was not significantly different between bivalve species regardless the crayfish species (Kruskal-Wallis test, $p>0.05$ ).

Regarding the percentage of preyed individuals by both crayfish species A. anatina presented the highest values, followed by U. delphinus, $P$. littoralis and C. fluminea (Table 3). Differences between both crayfishes were not significant (Pearson's chi-squared test, $p>0.05$ ).

Regarding the predation status (i.e. preyed or not preyed), no significant differences were found considering the sizes of the animals and thus, the success of predation did not depend on crayfish nor bivalve sizes (Welch test, $p>0.05$ ). In addition, predation success did not depend on crayfish or bivalve sizes, regardless of crayfish and bivalve species (Spearman's correlation, $p>0.05$ ) (Fig. S1). When only considering bivalves that were preyed, results showed that neither crayfish (Fig. S2A) nor bivalve (Fig. S2B) sizes affected the percentage of shell predation (Spearman's correlation, $p>0.05$ ).

Table 3

Percentage of preyed bivalves by Pacifastacus leniusculus and Procambarus clarkii.

\begin{tabular}{lllll}
\hline & \multicolumn{4}{l}{ Percentage of individuals preyed (\%) } \\
\cline { 2 - 5 } & A. anatina & U. delphinus & P. littoralis & C. fluminea \\
\hline Pacifastacus leniusculus & 60 & 40 & 35 & 0 \\
Procambarus clarkii & 45 & 30 & 25 & 0 \\
\hline
\end{tabular}


A

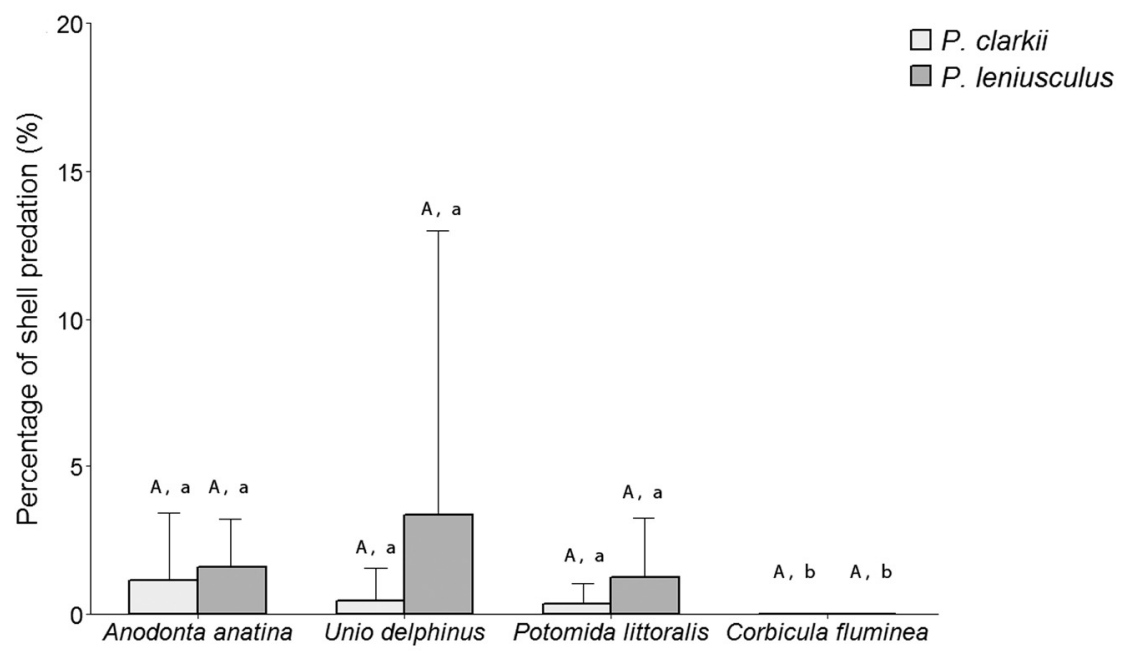

B

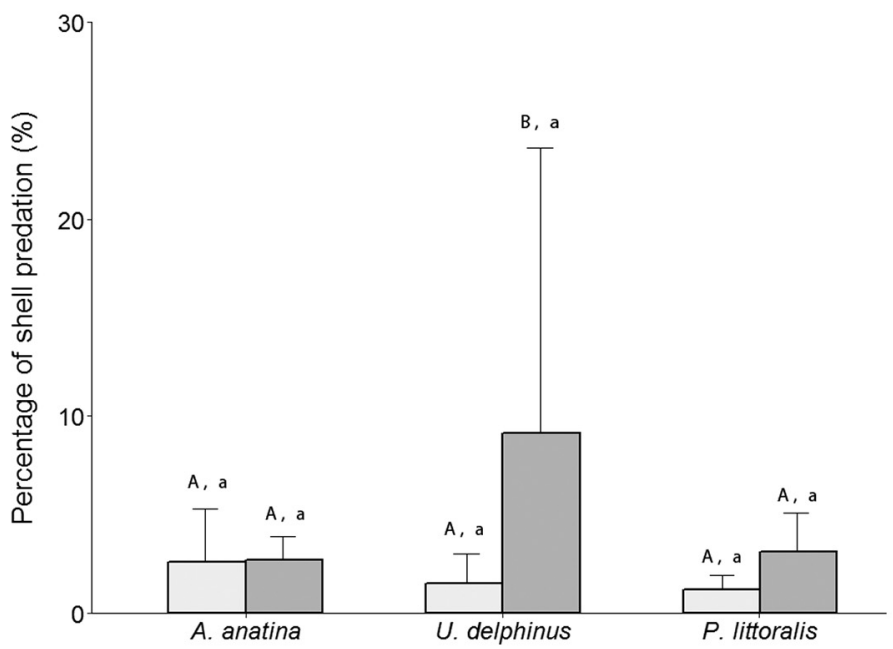

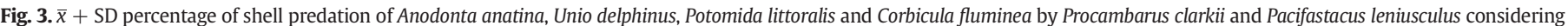

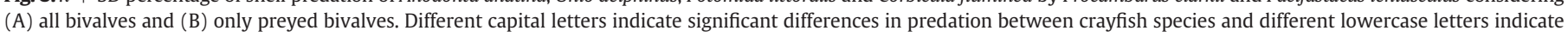
significant differences in predation between bivalve species.

\subsection{Experiment 2: prey preference}

When given a choice, $P$. clarkii and $P$. leniusculus preyed on the same bivalve species as in the first experiment. The percentages of preyed bivalves (Table 4) was different than the expected if crayfishes had no choice (Pearson's chi-squared test: $P$. leniusculus: $\chi^{2}(2)=38.44, p<$ 0.001; P. clarkii: $\chi^{2}(2)=48.17, p<0.001$ ), being A. anatina the most preyed bivalve species by both crayfish species.

\subsection{Experiment 3: crayfish competition}

When sharing the same space and prey, P clarkii was found to handle the bivalve significantly longer than P. leniusculus (Wilcoxon matchedpairs signed ranks test, $\mathrm{W}=35.00, p=0.039, N=10$ )(Fig. $4 \mathrm{~A}$ ). On average, and in $72 \mathrm{~h}, P$. clarkii handled bivalves for 27:43 min while $P$. leniusculus did it only for 3:10 min. During the experiments, two Louisiana crayfishes surpassed two hours of handling whereas their opponents handled those bivalves for, approximately, 14 and $6 \mathrm{~min}$. In one replicate none of the crayfishes handled the bivalve and the signal crayfish also did not handle the bivalve in other three replicates.
Procambarus clarkii was found to manipulate bivalves a number of times significantly higher ( $63.6 \%$ on average) than $P$. leniusculus (Wilcoxon matched-pairs signed ranks test, $\mathrm{W}=50.00, p=0.008$, $\mathrm{N}=10$ ) (Fig. 4B).

Procambarus clarkii was also the most aggressive crayfish species, initiating more agonistic bouts than $P$. leniusculus (Paired $t$-test, $\mathrm{t}(9)=$ $6.33, p<0.001$ ) (Fig. 4C). On average, the Louisiana crayfish initiated $77.9 \%$ of the fights, which translates to $55.8 \%$ more initiated agonistic bouts than the signal crayfish. There was one case where P. leniusculus initiated $50.0 \%$ of the agonistic bouts but on average this species initiated only $22.1 \%$ of the aggressive interactions.

\subsection{In situ validation}

Throughout the 51 sampling sites in Sabor River basin, 2800 (153 dead and preyed, and 2647 alive) bivalve specimens were found being 1531 identified as $U$. delphinus, 642 as A. anatina, 130 as P. littoralis, and 497 as $C$. fluminea (Fig. 5A). Native bivalves were found in all sampling sites except sites 2, 33 and 34 in Sabor River and sites 4, 5 and 6 in Maçãs River. Besides being the most abundant species, $U$. delphinus was 
Table 4

Average percentage (\%) of preyed bivalves (Anodonta anatina, Unio delphinus, Potomida littoralis and Corbicula fluminea) by Pacifastacus leniusculus and Procambarus clarkii when having prey as a choice.

\begin{tabular}{lllll}
\hline & \multicolumn{4}{l}{ Mean of preyed individuals' percentage (\%) } \\
\cline { 2 - 5 } & A. anatina & U. delphinus & P. littoralis & C. fluminea \\
\hline Pacifastacus leniusculus & 53.33 & 13.33 & 23.33 & 0 \\
Procambarus clarkii & 51.67 & 39.58 & 6.67 & 0 \\
\hline
\end{tabular}

also the most widespread, being present in 45 of the 51 sampling sites. A. anatina was found in 36 sites and $P$. littoralis was present in only five sites (Sabor River sites 7, 10 and 12 and Maçãs River sites 1 and 3). The invasive clam C. fluminea was found in 14 sites, which include all sites in Maçãs River and sites 4, 6, 7, 8, 9, 10, 11 and 20 in Sabor River.

Regarding the crayfish sampling, in total 1320 crayfishes were collected and $92.1 \%$ were identified as P. leniusculus and $7.9 \%$ as P. clarkii, being $P$. leniusculus significantly more abundant than $P$. clarkii (Wilcoxon matched-pairs signed ranks test, $\mathrm{W}=75.00, p=0.016, N=15$ ). Despite this, the signal crayfish was not found in four of the 15 surveyed sites, while P. clarkii was found in all sampling sites except one (Fig. 5B). There were no significant differences between the number of female and male crayfishes (Paired $t$-test, $p>0.05$ ); however, when analysing each crayfish species individually differences were found. Average female signal crayfish abundance was 5.8\% higher than its male counterpart (Paired $t$-test, $\mathrm{t}(14)=2.37, p=0.033$ ), while in the case of the Louisiana crayfish, males were $1.78 \%$ more abundant than females (Wilcoxon matched-pairs signed ranks test, $\mathrm{W}=61.00, p=0.049$ ).

No predation marks were found in any of $C$. fluminea specimens. On the other hand, all native species were found to be preyed by crayfishes (Fig. 5A). In addition, 156 of the native bivalves collected were found dead and presented characteristic marks of crayfish predation (see Fig. 1A and Machida and Akiyama, 2013). The percentage of shell predation of native bivalves varied between $1.0 \%$ and $45.0 \%$ for $A$. anatina (Fig. 6), $1.0 \%$ and $40.0 \%$ for U. delphinus (Fig. 6 ), and $1.0 \%$ and $10.0 \%$ for $P$. littoralis (data not shown). Potomida littoralis only showed signs of predation in Maçãs River site 1, which was the site with higher abundance of this species. In this site, 123 P. littoralis specimens were collected, $22.7 \%$ presented predation marks and the average percentage of shell predation was $3.8 \%$. All the collected bivalves with $>15.0 \%$ of their shell preyed were found dead except one $U$. delphinus specimen that was found alive with $25.0 \%$ of its shell preyed.

When comparing sites where both $U$. delphinus and $A$. anatina were present, results showed that predation was dependent on the river site
A

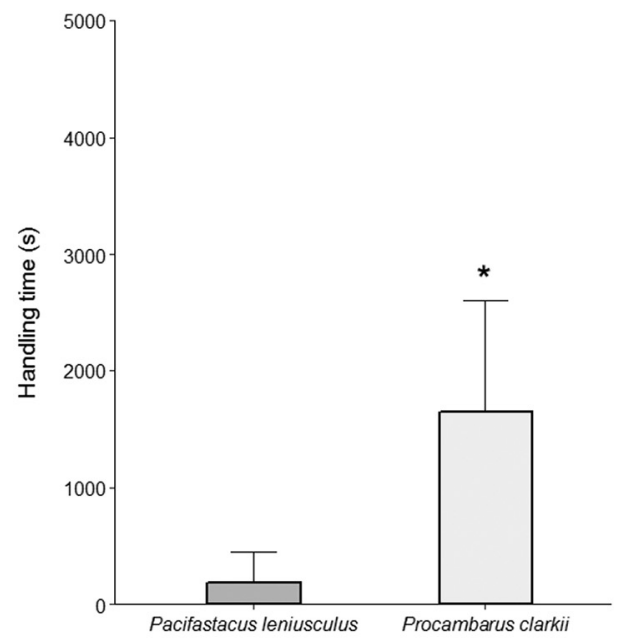

C

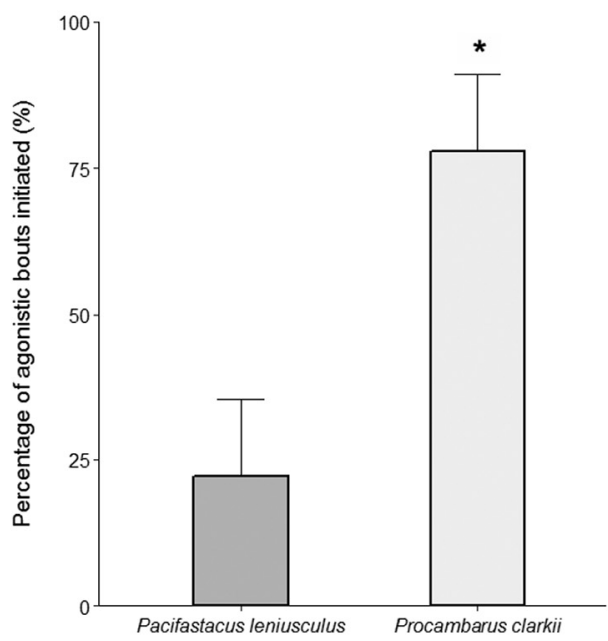

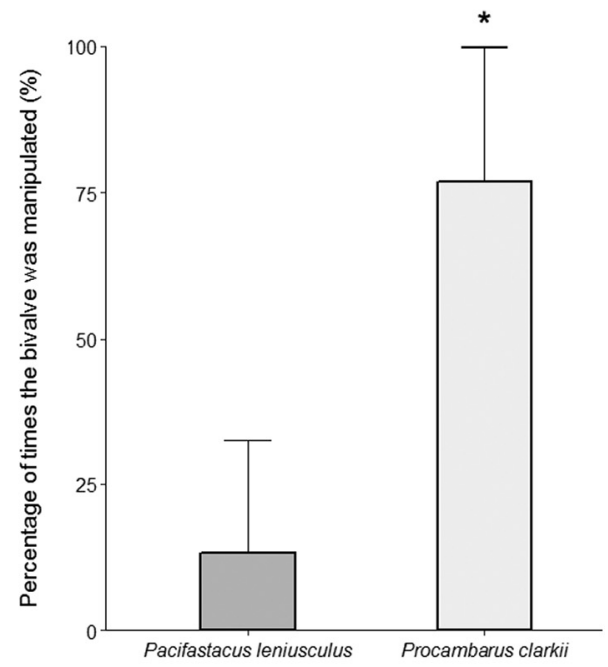


A

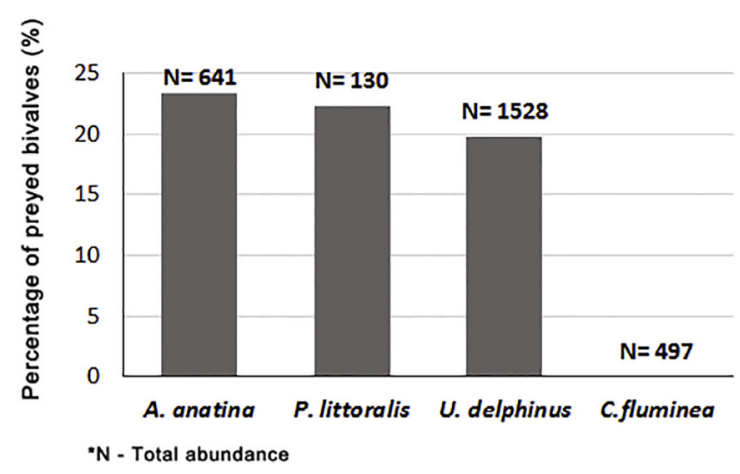

B

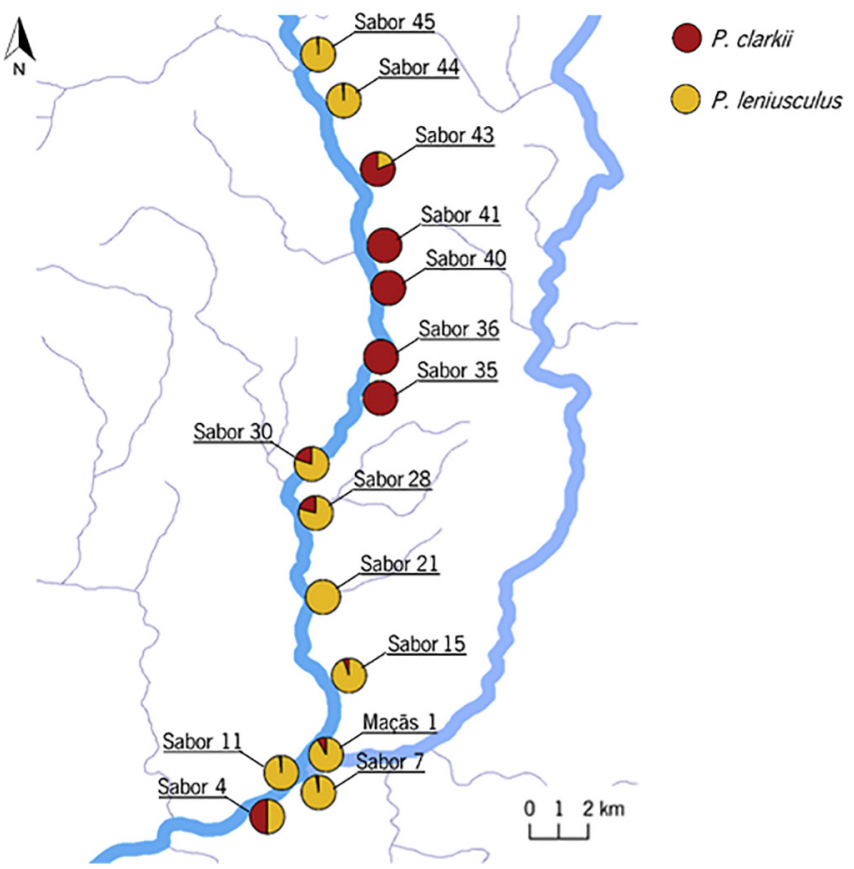

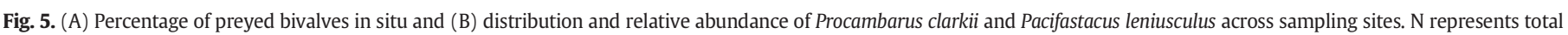
abundance.

and bivalve species, with a significant interaction between both factors (PERMANOVA, Table 5). PERMANOVA pair-wise comparisons showed differences on predation between A. anatina and $U$. delphinus in five of the analysed sites. On average, $A$. anatina had significantly higher percentage of shell predation in Sabor River sites 29 and 30, while $U$. delphinus had significantly higher percentage in Sabor River sites 18,26 and 27.

The percentage of shell predation varied between sampling sites for both $A$. anatina and $U$. delphinus. The percentage of preyed A. anatina and $U$. delphinus was not related to crayfish sex (Spearman's correlation, $p>0.05$ ) and no correlation was found between the average abundance of crayfish and the percentage of preyed bivalves (Spearman's correlation, $p>0.05$ ) (Table S1).

\section{Discussion}

In this study we showed that the invasive crayfishes $P$. clarkii and $P$. leniusculus can prey on native freshwater bivalves. This comes as no

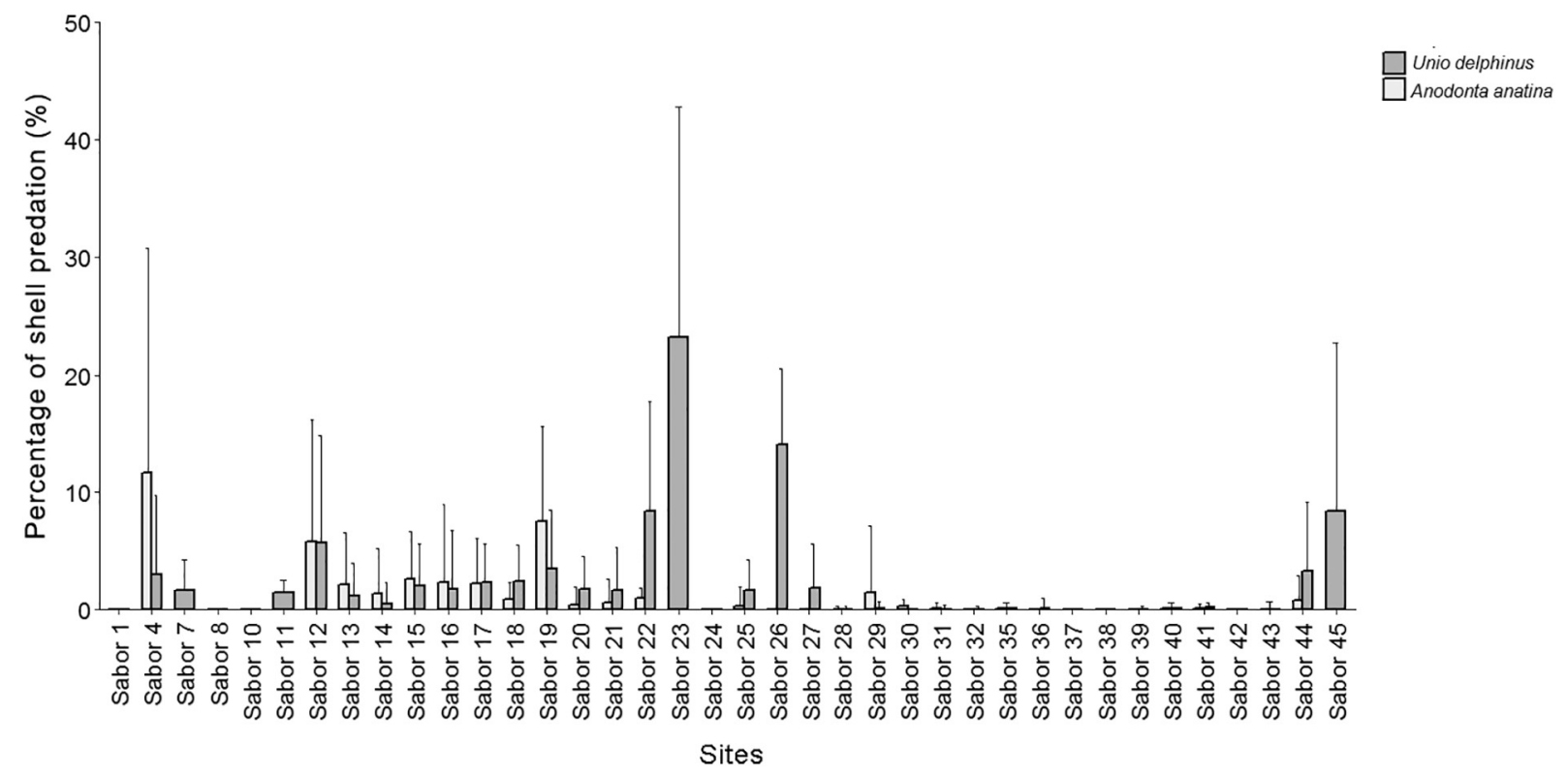

Fig. 6. $\bar{x}+$ SDof the percentage of shell predation of Anodonta anatina and Unio delphinus by sampling site. 
Table 5

Summary of PERMANOVA results on the effect of river site and bivalve species on shell predation by crayfishes.

\begin{tabular}{lllllll}
\hline Parameter & Effect & df & SS & MS & $\begin{array}{l}\text { Pseudo } \\
\text { F }\end{array}$ & P \\
& & & & & & \\
\hline Shell consumption & River site & 23 & 2483.2 & 107.97 & 11.555 & 0.001 \\
& Bivalve species & 1 & 43.86 & 43.86 & 4.694 & 0.034 \\
& $\begin{array}{l}\text { River site } \times \text { bivalve } \\
\text { species }\end{array}$ & 23 & 1413.3 & 61.45 & 6.576 & 0.001 \\
& Error & 1796 & 16,781 & 9.34 & & \\
\hline
\end{tabular}

surprise since other crayfish species are known to prey freshwater bivalves (e.g. Klocker and Strayer, 2004; Perry et al., 1997) and Machida and Akiyama (2013) showed that P. leniusculus was capable of preying two endangered Margaritifera species.

All native bivalve species used in this study were preyed and results indicated that $P$. leniusculus is a more efficient predator than P. clarkii. On average, and in the laboratory experiments, $P$. leniusculus predated a higher percentage of shell of $U$. delphinus than $P$. clarkii but this result was highly influenced by one specimen that was killed, which resulted in $44.4 \%$ of its shell eaten. If we exclude this specimen, the average shell predation of $U$. delphinus by the signal crayfish would have been much lower (3.0\% instead of $9.0 \%$ ), which was not significantly different than the average percentage predation by P. clarkii (1.5\%). Therefore, the possible differences between crayfish species should be interpreted with some caution. Anyway, several studies showed clear differences in the morphology of the mandibles of crayfish species (e.g. Capelli and Capelli, 1980; Kawai, 2012). For example, Harlioğlu (1996) studied P. leniusculus and Astacus leptodactylus (Eschscholtz, 1823) and suggested that $P$. leniusculus had a feeding advantage over $A$. leptodactylus, which could be explained by differences in their morphology and biology. Thus, the possible differences in bivalve predation between $P$. leniusculus and $P$. clarkii might be also partly explained by differences in morphology; however, future studies must be conducted to address this hypothesis.

When given a choice, both crayfish species preferred $A$. anatina as a prey. Of the four bivalve species used in this study, A. anatina has the most fragile and thin shells (Ilarri et al., 2015). Thus, it should be easier for crayfishes to handle and break $A$. anatina shells and energetically more profitable for crayfishes to prey $A$. anatina instead other species. The fact that $P$. littoralis was the less preyed native species in both choice and non-choice laboratory experiments may also be related with the shell thickness since this species presented the most robust and thick shell (Ilarri et al., 2015). Therefore, P. littoralis should be more resistant to crayfish predation and less profitable in terms of energy for both crayfishes. P. littoralis individuals were also the least preyed native bivalve by both crayfish species when they were allowed to choose their prey.

Potomida littoralis is the most threatened native bivalve species used in this study being listed as endangered by IUCN. Its populations in Portugal (and also in other European and North African countries) are very fragmented and have suffered major declines (Froufe et al., 2016; Lopes-Lima et al., 2014b and 2017) and this situation is also valid for the Sabor River basin (Sousa et al., 2012). Despite this, P. littoralis was the least preyed native species in the laboratory experiments. Additionally, only two specimens collected in the field were found dead and the cause did not appear to be directly related to crayfish predation due to the absence of the characteristic marks in the shells. This situation seems to indicate that crayfish predation may not play a major role on the decline of $P$. littoralis in the Sabor River basin (and possibly elsewhere), which may be explained by their thick and hard shells that probably turn the predation by both invasive crayfish more challenging.

Results suggest that $P$. clarkii and $P$. leniusculus predation did not directly cause a high mortality (and consequently a great reduction in abundance) on the native bivalve populations, given the low number of empty shells with predation marks found in the field survey.
However, these results should be interpreted with caution because many empty shells may have disappeared due to shell decay or washed to downstream areas. Anyway, and given the high number of alive bivalves presenting predation marks, it is possible that these species can still suffer sub-lethal effects from these invasive crayfishes. The damage caused to shells should have a physiological cost as energetic resources have to be mobilized for shell regeneration instead of growth and reproduction. In addition, every prey has to deal with the risk of being predated when feeding, thus having to balance the trade-off between predation risk and energy intake (Lima, 1998). Anti-predator behaviour may decrease prey energy intake and thus reduce its fitness and alter resource allocation, which can impact growth, reproduction and/or longterm survival (Johnson \& Smee, 2012; Lima, 1998). It has been reported that bivalves can perceive and respond to predation risk (Maire et al., 2010; Naddafiet al., 2007; Wilson et al. 2012). Some studies showed that bivalves filtration rates and the expelling of faeces and pseudofaeces are affected (i.e. reduced) by the presence of predators (Maire et al., 2010; Naddafi et al., 2007). Therefore, it may be reasonable to consider that freshwater bivalves used in the present study may also be affected in their filter feeding activity, due to the presence of $P$. clarkii and $P$. leniusculus, thus having lower fitness and consequently lower growth and reproduction rates. Furthermore, the non-lethal effects of these crayfishes could affect the functional role of bivalves (e.g. nutrient cycling, water filtration and purification, bioturbation of sediments), which may indirectly impact ecosystems.

Most predators prefer small preys when offered a range of different sizes (Juanes, 1992). However, in this study P. clarkii and P. leniusculus did not showed any preferences regarding the prey size. Machida \& Akiyama (2013) observed that $P$. liniusculus particularly injured Margaritifera spp. of medium size and suggested that this size class was the most suitable for crayfish manipulation. Nonetheless, and based on Machida and Akiyama (2013) results, these crayfishes may also kill small immature mussels. Besides this, in our study, crayfish size did not affect predation, which shows that smaller crayfishes are as capable of preying bivalves of various sizes as their larger counterparts. In addition, no correlation was found between crayfish sex and bivalve predation in the field suggesting that female and male crayfishes probably have the same level of impact on native freshwater bivalves.

No studies were found about the ability of $P$. leniusculus to prey C. fluminea. The lack of information about predator-prey interactions between P. leniusculus and C. fluminea impair us of making further comparisons. However, a few studies demonstrated that P. clarkii was able to prey on this invasive clam (e.g. Covich et al., 1981; Pereira et al., 2016). These earlier results on P. clarkii differ from the ones reported here that suggested that neither crayfish species was able to prey C. fluminea. The incoherence between the results of this study and those of others means that the absence of predation of the Asian clam is not necessarily due to the lack of ability of these crayfish species to prey it. Indeed, shell morphology and size may also affect the predation of $C$. fluminea. For example, Pereira et al. (2016) showed that $P$. clarkii was only able to prey on Asian clams with $<10 \mathrm{~mm}$, as demonstrated earlier by Covich et al. (1981). In our study, the smallest C. fluminea individuals used in the laboratory experiments measured $15 \mathrm{~mm}$, which may explain why no crayfish was able to prey this species. Furthermore, C. fluminea shell is thicker (Ilarri et al., 2015) and has a spherical shape, probably making it harder for crayfishes to manipulate and open it, unlike the other studied bivalves that have elongated and thinner shells, especially A. anatina and $U$. delphinus. Based on the available information (Bernardo et al., 2011; Crespo et al., 2015; Filipe et al., 2017; Sousa et al., 2012), the co-existence of these crayfish species and C. fluminea in Sabor River basin is relatively recent and thus, the absence of predation of $C$. fluminea in this study may be explained by the fact that both crayfish species have still not recognized this IAS as prey. Regardless of the reason behind the lack of predation of this IAS, P. clarkii and $P$. leniusculus may be able to affect $C$. fluminea recruitment as this species only becomes sexually mature when shell size reaches 6 to $10 \mathrm{~mm}$ 
(Sousa et al., 2008). However, our results clearly showed that both crayfish species have prey preference when it comes to bivalve species, and as generalist omnivores the probability of them preying $C$. fluminea in natural environments should be very low, as they have numerous and easier to handle alternative food sources, including native bivalves. Thus, $P$. clarkii and P. leniusculus would probably not significantly reduce C. fluminea abundance and should not be expected to act as control agents of this species in invaded ecosystems. In addition to other possible advantages of $C$. fluminea over the native bivalve species (e.g. rapid growth, early sexual maturity, more plastic feeding; FerreiraRodríguez et al., 2018; Novais et al., 2016; Sousa et al., 2008 and 2014), this invasive clam may also benefit by the lower predation pressure in the Sabor River basin and elsewhere (see also Castro et al., 2018). This advantage may increase the pressure of $C$. fluminea over the native bivalve populations.

Our laboratory experiments showed that $P$. clarkii is the dominant and more aggressive crayfish species. This is consistent with the results of Pearl et al. (2013), which showed that P. clarkii has the potential to locally displace $P$. leniusculus and that the signal crayfish avoided areas where $P$. clarkii was present. However, in our field validation $P$. leniusculus was more abundant than $P$. clarkii, which suggests that besides aggressiveness, other factors might be important. Procambarus clarkii may be more prone to predation by mammals (or other faunal groups) than $P$. leniusculus or the environmental conditions in the Sabor River basin are more favourable to P. leniusculus, among other hypotheses. For example, Gherardi et al. (2013) showed that water temperature can affect crayfish behaviour by intensifying or lowering their aggressiveness. Although competition between P. clarkii and $P$. leniusculus was confirmed in the laboratory experiments, and their niches overlap, these crayfishes have numerous feeding sources (Axelsson et al., 1997; Gherardi et al., 2001; Gherardi, 2006; Guan \& Wiles, 1998), which means that competition for food may be minimized in the field. Although competition for food may be low in the Sabor River basin, these crayfish species may still compete for shelter in order to hide from predators or stressful environmental conditions. Finally, our laboratory results also suggest that $P$. clarkii causes less damage to native bivalves; and thus, native bivalves present in ecosystems where only P. clarkii exists will, in theory, suffer less impacts than those where P. leniusculus occurs. However, this situation may be highly context dependent and should be further evaluated.

Even though the present study may increase the knowledge about the predatory behaviour of these invasive crayfishes on freshwater bivalves, there are still gaps to explore in order to better understand the dynamics of these relationships and their impacts. To our knowledge this is the first study assembling laboratory and field data demonstrating how the introduction of predators may affect freshwater bivalves, a basic information essential for the conservation of these animals. Finally, the information reported here has also management implications because any measures devoted to the conservation of native freshwater bivalves in ecosystems invaded by $P$. clarkii and/or P. leniusculus (or even other crayfish species) should take into account the role of these animals as important predators.

Supplementary data to this article can be found online at https://doi. org/10.1016/j.scitotenv.2018.08.341.

\section{Acknowledgements}

This work was supported by Portuguese FCT - Foundation for Science and Technology, Project FRESHCO: Multiple implications of invasive species on Freshwater Mussel co-extinction processes (contract PTDC/ AGR-FOR/1627/2014-04/SAICT/2015) and Project 3599- Promoting Scientific and Technological Development Production and the Constitution of Thematic Networks (3599-PPCDT), FEDER - European Community Funds. FCT also support M.L.L. with a doctoral grant (SFRH/BD/ 115728/2016). We thank the three anonymous referees for constructive suggestions.

\section{References}

Anderson, M.J., 2001. A new method for non-parametric multivariate analysis of variance. Austral. Ecol. 26, 32-46.

Axelsson, E., Brönmark, C., Sidenmark, J., Nyström, P., 1997. Crayfish predation on amphibian eggs and larvae. Amphibia-Reptilia 18, 217-228.

Bernardo, J.M., Costa, A.M., Bruxelas, S., Teixeira, A., 2011. Dispersal and coexistence of two non-native crayfish species (Pacifastacus leniusculus and Procambarus clarkii) in NE Portugal over a 10-year period. Knowl. Manag. Aquat. Ecosyst. 28.

Bondar, C.A., Zhang, Y., Richardson, J.S., Jesson, D., 2005. The conservation status of the freshwater crayfish, Pacifastacus leniusculus. British Columbia. Fisheries Management Report No. 117. BC Ministry of Water, Land and Air Protection Province of British Columbia. 23.

Capelli, G.M., Capelli, J.F., 1980. Hybridization between crayfish of the genus Orconectes: morphological evidence (Decapoda, Cambaridae). Crustaceana 39, 121-132.

Carvalho, F., Pascoal, C., Cássio, F., Sousa, R., 2016. Direct and indirect effects of an invasive omnivore crayfish on leaf litter decomposition. Sci. Total Environ. 541, 714-720.

Castro, P.S., Ilarri, M., Modesto, V., Antunes, C., Sousa, R., 2018. Palatability of the Asian clam Corbicula fluminea (Müller 1774) in an invaded system. Hydrobiologia 810, 97-108.

Covich, A., Dye, L., Mattice, J., 1981. Crayfish predation on Corbicula under laboratory conditions. Am. Midl. Nat. 105, 181-188.

Creed Jr., R.P., Reed, J.M., 2004. Ecosystem engineering by crayfish in a headwater stream community. North Am. Benthol. Soc. 23, 224-236.

Crespo, D., Dolbeth, M., Leston, S., Sousa, R., Pardal, M., 2015. Distribution of Corbicula fluminea (Müller, 1774) in the invaded range: a geographic approach with notes on species traits variability. Biol. Invasions 17, 2087-2101.

DAISIE Database, 2018. DAISIE European Invasive Alien Species Gateway. http://www.europe-aliens.org/.

Ferreira-Rodríguez, N., Sousa, R., Pardo, I., 2018. Negative effects of Corbicula fluminea over native freshwater mussels. Hydrobiologia 810, 85-95.

Filipe, A.F., Quaglietta, L., Ferreira, M., Magalhães, M.F., Beja, P., 2017. Geostatistical distribution modelling of two invasive crayfish across dendritic stream networks. Biol. Invasions 19, 2899-2912.

Froufe, E., Prié, V., Faria, J., Ghamizi, M., Gonçalves, D., Gürlek, M.E., Karaouzas, I., Kebapçi, Ü., Sereflisan, H., Sobral, C., Sousa, R., Teixeira, A., Varandas, S., Zogaris, S., Lopes-Lima, M., 2016. Phylogeny, phylogeography, and evolution in the Mediterranean region: news from a freshwater mussel (Potomida, Unionida). Mol. Phylogenet. Evol. 100, 322-332.

García-Berthou, E., Alcaraz, C., Pou-Rovira, Q., Zamora, L., Coenders, G., Feo, C., 2005. Introduction pathways and establishment rates of invasive aquatic species in Europe. Can. J. Fish. Aquat. Sci. 62, 453-463.

Gherardi, F., 2006. Crayfish invading Europe: the case study of Procambarus clarkii. Mar. Freshw. Behav. Physiol. 39, 175-191.

Gherardi, F., Renai, B., Corti, C., 2001. Crayfish predation on tadpoles: a comparison between a native (Austropotamobius pallipes) and an alien species (Procambarus clarkii). Bull. Français la Pêche la Piscic. 361, 659-668.

Gherardi, F., Coignet, A., Souty-Grosset, C., Spigoli, D., Aquiloni, L., 2013. Climate warming and the agonistic behaviour of invasive crayfishes in Europe. Freshw. Biol. 58, $1958-1967$.

Guan, R., Wiles, P., 1998. Feeding ecology of the signal crayfish Pacifastacus leniusculus in a British lowland river. Aquaculture 169, 177-193.

Gutiérrez, J.L., Jones, C.G., Sousa, R., 2014. Toward an integrated ecosystem perspective of invasive species impacts. Acta Oecol. 54, 131-138.

Gutiérrez-Yurrita, P.J., Sancho, G., Bravo, M.A., Baltanás, A., Montes, C., 1998. Diet of the red swamp crayfish Procambarus clarkii in natural ecosystems of the Doñana National Park temporary fresh-water marsh (Spain). J. Crustac. Biol. 18, 120-127.

Gutiérrez-Yurrita, P.J., Martinez, J.M., Ilhéu, M., Bravo-Utrera, M.A., Bernardo, J.M., Montes, C., 1999. The status of crayfish populations in Spain and Portugal. In: Gherardi, F., Holdich, D.M. (Eds.), Crayfish in Europe as Alien Species. How to Make the Best of a Bad Situation?A.A. Balkema, Rotterdam, pp. 161-192.

Harlioğlu, M., 1996. Comparative Biology of the Signal Crayfish, Pacifastacus leniusculus (Dana), and the Narrow-clawed Crayfish, Astacus leptodactylus Eschscholtz.

Henttonen, P., Huner, J.V., 1999. The introduction of alien species of crayfish in Europe: A historical introduction. In: Gherardi, F., Holdich, D.M. (Eds.), Crayfish in Europe as Alien Species. How to Make the Best of a Bad Situation?A.A. Balkema, Rotterdam, pp. 13-30.

Hobbs, H.H., Jass, J.P., Huner, J.V., 1989. A review of global crayfish introductions with particular emphasis on two North American species (Decapoda, Cambaridae). Crustaceana 56, 299-316.

Howard, J.K., Cuffey, K.M., 2006. The functional role of native freshwater mussels in the fluvial benthic environment. Freshw. Biol. 51, 460-474.

Ilarri, M., Souza, A.T., Sousa, R., 2015. Contrasting decay rates of freshwater bivalves' shells: aquatic versus terrestrial habitats. Limnol. Manag. Inl. Waters 51, 8-14.

Johnson, K., Smee, D., 2012. Size matters for risk assessment and resource allocation in bivalves. Mar. Ecol. Prog. Seires 462, 103-110.

Johnson, M.F., Rice, S.P., Reid, I., 2010. Topographic disturbance of subaqueous gravel substrates by signal crayfish (Pacifastacus leniusculus). Geomorphology 123, 269-278.

Juanes, F., 1992. Why do decapod crustaceans prefer small-sized molluscan prey? Mar. Ecol. Prog. Seires 87, 239-249.

Kawai, T., 2012. Morphology of the mandible and gill of the Asian freshwater crayfish Cambaroides (Decapoda: Cambaridae) with implications for their phylogeny. J. Crustac. Biol. 32, 15-23.

Klocker, C., Strayer, D., 2004. Interactions among an invasive crayfish (Orconectes rusticus), a native crayfish (Orconectes limosus), and native bivalves (Sphaeriidae and Unionidae). Northeast. Nat. 11, 167-178. 
Lima, S., 1998. Nonlethal effects in the ecology of predator-prey interactions. Bioscience $48,25-34$.

Lopes-Lima, M., Teixeira, A., Froufe, E., Lopes, A., Varandas, S., Sousa, R., 2014a. Biology and conservation of freshwater bivalves: past, present and future perspectives. Hydrobiologia 735, 1-13.

Lopes-Lima, M., Prie, V., Seddon, M.B., 2014b. Potomida littoralis. IUCN Red List Threat. Species 2014 e.T156136A.

Lopes-Lima, M., Sousa, R., Geist, J., Aldridge, D.C., Araujo, R., Bergengren, J., Bespalaya, Y., Bódis, E., Burlakova, L., Van Damme, D., Douda, K., Froufe, E., Georgiev, D., Gumpinger, C., Karatayev, A., Kebapci, U., Killeen, I., Lajtner, J., Larsen, B., Lauceri, R., Legakis, A., Lois, S., Lundberg, S., Moorkens, E., Motte, G., Nagel, K.-O., Ondina, P., Outeiro, A., Paunovic, M., Prié, V., von Proschwitz, T., Riccardi, N., Rudzite, M., Rudzitis, M., Scheder, C., Seddon, M., Sereflisan, H., Simic, V., Sokolova, S., Stoeckl, K., Taskinen, J., Teixeira, A., Thielen, F., Trichkova, T., Varandas, S., Vicentini, H., Zajac, K., Zajac, T., Zogaris, S., 2017. Conservation status of freshwater mussels in Europe: state of the art and future challenges. Biol. Rev. 92, 572-607.

Lopes-Lima, M., Burlakova, L.E., Karatayev, A.Y., Mehler, K., Seddon, M., Sousa, R., 2018. Conservation of freshwater bivalves at the global scale: diversity, threats and research needs. Hydrobiologia 810, 1-14.

Machida, Y., Akiyama, Y.B., 2013. Impacts of invasive crayfish (Pacifastacus leniusculus) on endangered freshwater pearl mussels (Margaritifera laevis and M. togakushiensis) in Japan. Hydrobiologia 720, 145-151.

Maire, O., Merchant, J., Bulling, M., Teal, L., 2010. Indirect effects of non-lethal predation on bivalve activity and sediment reworking. J. Exp. 395, 30-36.

Matsuzaki, S.S., Usio, N., Takamura, N., Washitani, I., 2009. Contrasting impacts of invasive engineers on freshwater ecosystems: an experiment and meta-analysis. Oecologia 158, 673-686.

Naddafi, R., Eklöv, P., Pettersson, K., 2007. Non-lethal predator effects on the feeding rate and prey selection of the exotic zebra mussel Dreissena polymorpha. Oikos 116, 1289-1298.

Novais, A., Dias, E., Sousa, R., 2016. Inter- and intraspecific variation of carbon and nitrogen stable isotope ratios in freshwater bivalves. Hydrobiologia 765, 149-158.

Nyström, P., Brönmark, C., Graneli, W., 1996. Patterns in benthic food webs: a role for omnivorous crayfish? Freshw. Biol. 36, 631-646.

Olden, J., Poff, N., Douglas, M., Douglas, M., 2004. Ecological and evolutionary consequences of biotic homogenization. Trends Ecol. Evol. 19, 18-24.

Pearl, C., Adams, M., McCreary, B., 2013. Habitat and co-occurrence of native and invasive crayfish in the Pacific Northwest, USA. Aquat. Invasions 8, 171-174.

Pereira, J., Pinho, S., Ré, A., Costa, P., Costa, R., Gonçalves, F., Castro, B., 2016. Biological control of the invasive Asian clam, Corbicula fluminea: can predators tame the beast? Hydrobiologia 779, 209-226.

Perry, W.L., Lodge, D.M., Lamberti, G.A., 1997. Impact of crayfish predation on exotic zebra mussels and native invertebrates in a lake-outlet stream. Can. J. Fish. Aquat. Sci. 54, 120-125.

R Core Team, 2015. R: A language and environment for statistical computing. R Foundation for Statistical Computing, Vienna, Austria http://www.R-project.org/.
Sala, O.E., Chapin, F.S., Armesto, J.J., Berlow, E., Bloomfield, J., Dirzo, R., Huber-Sanwald, E. Huenneke, L.F., Jackson, R.B., Kinzig, A., Leemans, R., Lodge, D.M., Mooney, H.A. Oesterheld, M., Poff, N.L.R., Sykes, M.T., Walker, B.H., Walker, M., Wall, D.H., 2000 Global biodiversity scenarios for the year 2100. Science 287, 1770-1774.

Simberloff, D., Martin, J.L., Genovesi, P., Maris, V., Wardle, D.A., Aronson, J., Courchamp, F., Galil, B., García-Berthou, E., Pascal, M., Pyšek, P., Sousa, R., Tabacchi, E., Vilà, M., 2013. Impacts of biological invasions: what's what and the way forward. Trends Ecol. Evol. 28, 58-66.

Simon, K.S., Townsend, C.R., 2003. Impacts of freshwater invaders at different levels of ecological organisation, with emphasis on salmonids and ecosystem consequences. Freshw. Biol. 48, 982-994.

Sousa, R., Antunes, C., Guilhermino, L., 2008. Ecology of the invasive Asian clam Corbicula fluminea (Müller, 1774) in aquatic ecosystems: an overview. Ann. Limnol. Int. J. Limnol. 44, 85-94.

Sousa, R., Morais, P., Dias, E., Antunes, C. 2011. Biological invasions and ecosystem functioning: time to merge. Biol. Invasions 13, 1055-1058.

Sousa, R., Varandas, S., Cortes, R., Teixeira, A., 2012. Massive die-offs of freshwater bivalves as resource pulses. Int. J. Limnol. 48, 105-112.

Sousa, R., Freitas, F.E.P., Mota, M., Nogueira, A.J.A., Antunes, C., 2013. Invasive dynamics of the crayfish Procambarus clarkii (Girard, 1852) in the international section of the River Minho (NW of the Iberian Peninsula). Aquat. Conserv. Mar. Freshwat. Ecosyst. 23, 656-666.

Sousa, R., Novais, A., Costa, R., Strayer, D.L., 2014. Invasive bivalves in fresh waters: impacts from individuals to ecosystems and possible control strategies. Hydrobiologia 735, 233-251.

Strayer, D.L., 2010. Alien species in fresh waters: ecological effects, interactions with other stressors, and prospects for the future. Freshw. Biol. 55, 152-174.

Vaughn, C.C., Hakenkamp, C.C., 2001. The functional role of burrowing bivalves in freshwater ecosystems. Freshw. Biol. 46, 1431-1446.

Vaughn, C.C., Nichols, S.J., Spooner, D.E., 2008. Community and foodweb ecology of freshwater mussels. J. North Am. Benthol. Soc. 27, 409-423.

Vilà, M., Basnou, C., Pyšek, P., Josefsson, M., Genovesi, P., Gollasch, S., Nentwig, W., Olenin, S., Roques, A., Roy, D., Hulme, P.E., 2010. How well do we understand the impacts of alien species on ecosystem services? A pan-European, cross-taxa assessment. Front. Ecol. Environ. 8, 135-144.

Vitousek, P.M. D'Antonio, C.M., Loope, L.L, Rejmánek, M. Westbrooks, R, 1997. Introduced Species: A Significant Component of Human-caused Global Environmental Change the Scope and Distribution of Invasions. 21 pp. 1-16.

Williams, J.D., Warren, M.L., Cummings, K.S., Harris, J.L., Neves, R.J., 1993. Conservation status of freshwater mussels of the United States and Canada. Fisheries 18, 6-22.

Wilson, C., Arnott, G., Elwood, R., 2012. Freshwater pearl mussels show plasticity of responses to different predation risks but also show consistent individual differences in responsiveness. Behav. Process. 89, 299-303.

Zar, J., 2010. Biostatistical Analysis. fifth ed. Prentice Hall, New Jersey. 